\title{
Protein Concentration and Vigor of Imbibed Density-separated Primula Seed
}

\author{
Mehrassa Khademi', David S. Koranski, and Joan Peterson \\ Department of Horticulture, Iowa State University, Ames, IA 50011
}

Additional index words. germination, Primula acaulis, SDS-PAGE

Abstract. Seeds of Primula acaulis (L.) J. Hill 'Dukaat Helderrose' were imbibed for 48 h at $18 \mathrm{C}$, and Maltrin 600 solution was used to separate them into density classes of $1.10,1.12$,

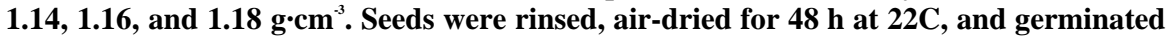
at $18 \mathrm{C} ; 80 \%$ were separated into density classes between 1.16 and $1.18 \mathrm{~g} \cdot \mathrm{cm}^{-3}$. Percentages of germination and high-vigor seedlings were significantly greater for seeds with densities $>1.14 \mathrm{~g} \cdot \mathrm{cm}^{-3}$. Soluble protein concentration increased with density, whereas insoluble protein concentration was unchanged. Distinct protein groups with estimated molecular weights of $\approx 50,33$, and $25 \mathrm{kDa}$ were present in the protein profile of nonseparated imbibed

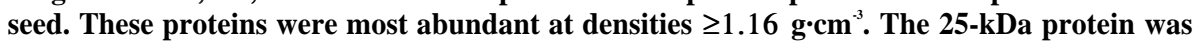
present only in higher density seed. Presence of an additional 14-kDa protein was noted in the insoluble protein profile. Certain proteins in the soluble protein fraction maybe used to test for seed vigor.

Rapid establishment of a complete and uniform stand is required for successful crop production (Hey and Gamble, 1987). Seed quality is often the major factor controlling crop performance and productivity (Bartee and Krieg, 1974). Several methods have been developed to improve seed quality through separation of dead or poor-quality seeds (Johnston et al., 1978; Taylor and Kenny, 1985; Taylor et al., 1982). Density separation and elimination of seed can improve germination and emergence of vegetable crops (Hill et al., 1989; Taylor and Kenny, 1985) and of some cotton (Gossypium hirsutum L.) cultivars (Bartee and Krieg, 1974). High-density seed have proved to be of high quality and to result in vigorous seedlings (Krieg and Bartee, 1975). Positive correlation of vigor with seed reserve materials such as proteins (total nitrogen), carbohydrates, and lipids have been reported in several crops (Bartee and Krieg, 1974; Smith and Weber, 1968; Taylor et al., 1982).

Poor germination (40\% to $50 \%$ ) and low seedling vigor are significant problems associated with primula production. The purpose of this study was to determine whether density separation could be used to improve germination and vigor of primula seed and whether the protein content of seed is representative of

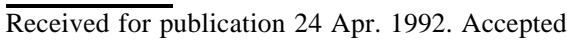
for publication 29 Dec. 1992. Journal paper no. J14892 of the Iowa Agriculture and Home Economics Experiment Station, Ames, project no. 2612. We thank Zaadunie, Enkuizen, The Netherlands, for providing Primula acaulis seeds and supporting this research. The cost of publishing this paper was defrayed in part by the payment of page charges. Under postal regulations, this paper therefore must be hereby marked advertisement solely to indicate this fact.

${ }^{1}$ To whom reprint requests should be addressed. Current address: Bodger Seeds, 1851 W. Olive, Lompoc, CA 93436. ef percentages, by weight, of Maltin/water and 0.92 , respectively.
$24.5 \% / 75.5 \%, 29.2 \% / 70.8 \%, 33.9 \% / 66.1 \%$, $38.6 \% / 61.4 \%$, and $43.3 \% / 56.7 \%$, respectively. The density of each solution was verified with a specific-gravity hydrometer. After separation, seeds were rinsed with running distilled water for $2 \mathrm{~min}$, air-dried at $22 \mathrm{C}$ for $48 \mathrm{~h}$, and tested for viability, germination, seedling vigor, and soluble/insoluble protein concentrations. Samples of soluble and insoluble proteins were subjected to sodium dodecylsulfate polyacrylamide gel electrophoresis (SDS-PAGE). The experiment was arranged in a completely random design with four replications, except for protein content, which had three replications. Regression analysis was used to characterize the relations between seed density and viability, germination, seedling vigor, and protein content.

Viability, germination, and vigor. Seeds were soaked overnight in $1 \%$ tetrazolium solution at 30C for the viability test (Moore, 1985). Samples of 50 seeds from each density level were placed in transparent acrylic germination boxes $(12 \times 12 \times 3 \mathrm{~cm})$ with two layers of moist blue blotter paper (Anchor Paper, St. Paul, Minn.). Boxes were kept in a growth chamber at $18 \mathrm{C}$ with a continuous photosynthetic photon flux of $20 \mathrm{~mol} \cdot \mathrm{s}^{-1} \cdot \mathrm{m}^{-2}$ provided by $115-\mathrm{W}$ cool-white fluorescent and $25-\mathrm{W}$ incandescent lamps, 3:1 ratio. Germinated seeds (radicle length $=2$ to $3 \mathrm{~mm}$ ) were counted daily for 21 days. On day 21 , germination percentages and the number of high-vigor seedlings (open cotyledon $>8.0 \mathrm{~mm}$, hypocotyl $>4.0 \mathrm{~mm}$, and root length $>10.0 \mathrm{~mm}$ ) were calculated.

Protein content and SDS-PAGE. Samples of seeds $(20 \mathrm{mg})$ from each density level were ground in 300@ of 5 mm tris- $\mathrm{HCl}$ at $\mathrm{pH} 7.0$ over ice. Extracts were centrifuged for $20 \mathrm{~min}$

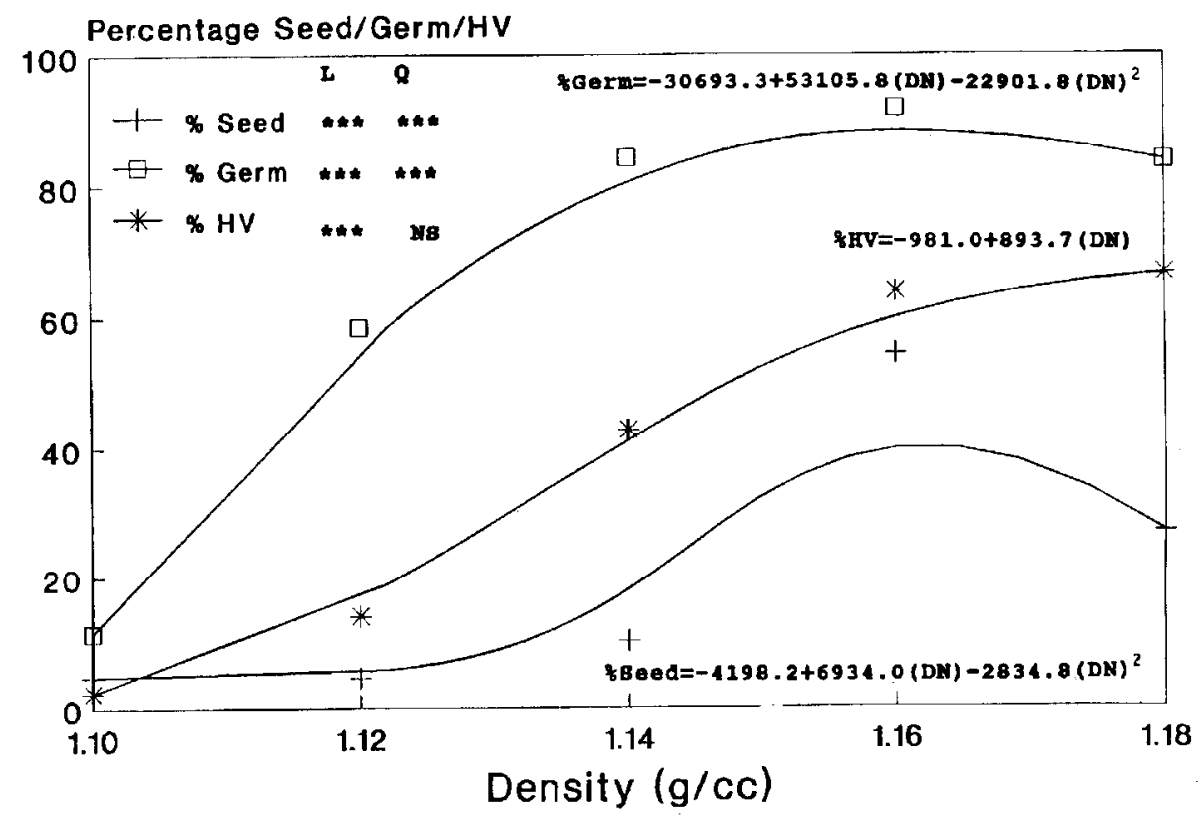

Fig. 1.Percentage of primula seed separated at each density class, percentage of germination, and percentage of high vigor (HV) (seedlings with open cotyledon $>8.0 \mathrm{~mm}$, hypocotyl $>6.0 \mathrm{~mm}$, and root length $>10.0$ $\mathrm{mm}$ ). Seeds were imbibed for $48 \mathrm{~h}$ at $18 \mathrm{C}$ and separated based on density in Maltrin solutions of $\mathrm{D}=1.10$ to $1.18 \mathrm{~g} \cdot \mathrm{cm}^{-3}$.***, Ns = Significant at $P \leq 0.001$ or nonsignificant, respectively, for linear (L) or quadratic $(Q)$ regression. The $r^{2}$ for percent seed, percent germination, and percent HV were $0.97,0.89$, 
Table 1. Soluble and insoluble protein concentration and percent viability of primula seed. Seeds were imbibed for $48 \mathrm{~h}$ at $18 \mathrm{C}$ and separated, based on density, in Maltrin solution of $\mathrm{D}=1.10$ to $1.18 \mathrm{~g} \cdot \mathrm{cm}^{-3}$.

\begin{tabular}{lccc}
\hline \hline & & \multicolumn{3}{c}{ Protein } \\
\cline { 3 - 4 } $\begin{array}{l}\text { Density } \\
\left(\mathrm{g} \cdot \mathrm{cm}^{-3}\right)\end{array}$ & $\begin{array}{c}\text { Viability } \\
(\%)\end{array}$ & $\begin{array}{c}\text { Soluble } \\
\left(\mathrm{mg}^{\mathbf{2}}\right)\end{array}$ & $\begin{array}{c}\text { Insoluble } \\
\left(\mathrm{mg}^{-1} \mathrm{~g}^{-1}\right)\end{array}$ \\
\hline 1.10 & 8 & 26 & 59 \\
1.12 & 61 & 29 & 58 \\
1.14 & 83 & 34 & 57 \\
1.16 & 89 & 35 & 61 \\
1.18 & 90 & 38 & 59 \\
Linear & $* * *$ & $* * *$ & NS \\
Quadratic & $\mathrm{NS}$ & $\mathrm{NS}$ & NS \\
$r^{2}$ & 0.96 & 0.62 & -- \\
\hline
\end{tabular}

${ }^{z}$ Seeds were soaked overnight in $1 \%$ tetrazolium solution at $30 \mathrm{C}$ for viability test ***, Ns Significant at $P=0.001$ or nonsignificant, respectively, for linear or quadratic regression.

at $11,000 \times g$. Twenty microliters of the supernatant were subjected to SDS-PAGE (0.75 $\mathrm{mm}$ discontinuous slab gel, $0.1 \%$ SDS), according to the method of Laemmli (1970). The remaining supernatant was used to measure water-soluble protein content according to the modified micro-Lowry method (Peterson, 1977). The pellet was freeze-dried overnight and dissolved in a $1: 1$ solution $(\mathrm{v} / \mathrm{v})$ of $5 \%$ SDS : $0.5 \mathrm{~N} \mathrm{NaOH}$ (Thorn, 1978). Extracts were centrifuged, and $6 \mu \mathrm{l}$ of the supernatant subjected to SDS-PAGE. The remaining sample was used to measure the insoluble protein concentration, as described for soluble protein.

Seed density had significant quadratic relation to the percentage of germination and the percentage of seeds separating at various densities (Fig. 1); $80 \%$ of seeds separated at 1.16 and $1.18 \mathrm{~g} \cdot \mathrm{cm}^{-3}$. Those separated at $\mathrm{D}=1.10$, 1.12 , and 1.14 comprised $20 \%$ of the total (Fig. 1). Although $>80 \%$ of seeds of $\mathrm{D}=1.14$ germinated, only half had high vigor. The same was true for $\mathrm{D}=1.12$ seeds having a relatively high germination percentage. Highvigor seedlings had a significant linear relation to seed density, and as seed density increased, so did percentages of germination and high vigor. According to the tetrazolium test (Table 1), the percentage of viable seed also increased with density.

Percent seed germination (radicle protrusion) is not always an accurate or reliable indicator of vigor. As shown in this study (Fig. 1), a seed lot with germination $>90 \%$ does not guarantee $90 \%$ to be vigorous. Primula seeds with densities $>1.14 \mathrm{~g} \cdot \mathrm{cm}^{-3}$ were quality seeds and produced the most high-vigor seedlings.
Similar relations have been shown for cotton (Leffler and Williams, 1983) and for some vegetable seeds (Hill et al., 1989). The relation of seed density to seed quality makes density separation a simple, efficient method of upgrading seed quality by removing low-density seeds (Hill et al., 1989; Krieg and Bartee, 1975).

In cotton, seed density was closely related to embryo maturity. Thus, Krieg and Bartee (1975) recommended that seed separation for improving seed quality be based on density rather than on other seed properties, such as weight or size. In contrast, seed size or density did not improve vigor in soybean (Glycine max L.) seed lots (Hey and Gamble, 1987). Primula seeds were separated into groups for small, medium, large, and extra-large seeds. Subsequently, the seeds of each group were separated according to density. Because each size group showed the same pattern of separation as did the original mixed seed, seed size did not relate to seed density (data not presented).

Soluble protein concentration increased with density, whereas insoluble protein concentration did not (Table 1; Fig. 2, lanes 1 to 6). Distinct protein groups with estimated molecular weights of 50,33 , and $25 \mathrm{kDa}$ were present in the protein profile of nonseparated imbibed seeds (Fig. 2, lane 7). These proteins were most abundant at densities of 1.16 and $1.18 \mathrm{~g} \cdot \mathrm{cm}^{-3}$. An additional 14-kDa protein was noticed in the insoluble protein profile (Fig. 2B)

Positive correlation of seed density with protein has been reported for wheat (Triticum



Fig. 2. SDS-PAGE profile of soluble $(A)$ and insoluble $(B)$ proteins extracted from density-separated primula seeds. Lanes 1 to 6, seeds of $D=1.08,1.10,1.12$, $1.14,1.16$, and $1.18 \mathrm{~g} \cdot \mathrm{cm}^{-3}$, respectively. Lane 7 presents nonseparated imbibed seed. $\mathrm{S}=$ standard molecular weight in kilodaltons. 
aestivum L.) (Taylor et al., 1982) and for some cotton cultivars (Bartee and Krieg, 1974). Leffler and Williams (1 983), however, did not confirm the protein-density relation for other cotton cultivars, although they did report increasing amounts of lipid content of the same pattern as the soluble protein exhibited in primula. In primula, major soluble protein concentration differences have occurred between densities lower and higher than 1.14 $\mathrm{g} \cdot \mathrm{cm}^{-3}$ (Table 1; Fig. 2A). Although $>80 \%$ of seeds of $\mathrm{D}=1.14 \mathrm{~g} \cdot \mathrm{cm}^{-3}$ germinated, the number of high-vigor seedlings in this group was low (Fig. 1). Seeds of D = 1.16 and 1.18 $\mathrm{g} \cdot \mathrm{cm}^{-3}$ had higher percentages of high-vigor seedlings and the highest concentrations of soluble protein. A $30 \%$ difference between the percentages of germination and of high-vigor seedlings at $\mathrm{D}=1.16 \mathrm{~g} \cdot \mathrm{cm}^{-3}$ indicates that the factors required for germination were probably different from those required for seedling vigor (Fig. 1). Another explanation could be that seeds of high terminability separate at the same density as do high-vigor seeds. If so, refining the separation method might remove this bias.

Insoluble protein concentrations did not differ significantly by density (Table 1; Fig. $2 \mathrm{~B})$, which suggests that the concentration of protein per se may be unconnected to seedling vigor. The major difference in protein profiles at low and high densities was the accumulation of a protein of $25 \mathrm{kDa}$ molecular weight (Fig. 2A). It seems, therefore, that the ability to convert enzymatically insoluble to watersoluble protein in high-vigor seedling is slower or absent in low-vigor seeds (Khademi et al., 1991 ). Thus, the presence of certain proteins or enzymes in the protein extracts of imbibed primula seed may be appropriate tools for testing seed vigor.

\section{Literature Cited}

Bartee, S.N. and D.R. Krieg, 1974. Cottonseed density: Associated physical and chemical properties of 10 cultivars. Agron. J. 66:433-435.

Hill, H.J., A.G. Taylor, and T.G. Min. 1989. Density separation of imbibed and primed vegetable seeds. J. Amer. Soc. Hort. Sci. 114:661-665.

Hoy, D.J. and E.E. Gamble. 1987. Field performance in soybean with seeds of differing size and density. Crop Sci. 27:121-126.

Johnston, S.K., R.H. Crowley, and D.S. Murray. 1978. Separating seed by species with $\mathrm{CaCl}$ solutions. Weed Sci. 26:213-2 15.

Khademi, M., D.S. Koranski, D.S. Hannapel, D.J. Gladon, and J.S. Burris. 1991. Storage-protein degradation and aminopeptidase activity during germination of stressed and nonstressed impatiens (Impatiens wallerana) seeds. Seed Sci, Technol. 19:403-412.

Krieg, D.R. and S.N. Bartee. 1975. Cottonseed density: Associated germination and seedling emergence properties. Agron. J. 67:343-347,

Laemmli, U.K. 1970. Cleavage of structural proteins during the assembly of the head of bacteriophage T4. Nature (London) 227:680-681,

Leffler, H.R. and R.D. Williams. 1983, Seed density classification influences germination and seedling growth of cotton. Crop Sci. 23:161-165.

Moore, R.P. 1985. Handbook of tetrazolium testing. Intl. Seed Testing Assn., Zurich, Switzerland.

Peterson, G.L. 1977. A simplification of the protein assay method of Lowry et al. which is more generally applicable. Anal. Biochem. 83:346356.

Smith, R.R. and C.R. Weber. 1968. Mass selection by specific gravity for protein and oil in soybean population. Crop Sci. 8:373-377.

Taylor, A.G. and T.J. Kenny. 1985. Improvement of germinated seed quality by density separation. J. Amer. Soc. Hort. Sci. 110:347-349.

Taylor, A.G., A.M. McCarthy, and E.M. Chirco, 1982. Density separation of seeds with hexane and chloroform. J. Seed Technol. 7:78-83.

Thorn, C.J.R. 1978. Techniques for determining protein concentration, p. 1-18. In: H.L, Kornberg (ed.). Techniques in protein and enzyme biochemistry. Elsevier/North Holland Biomedical, Amsterdam, The Netherlands. 